\title{
Social Entrepreneurship and Empowerment of Rural Women: Artemali Case
}

\author{
Villanueva Lendechy Héctor Manuel*, Tapia Villagómez Ivonne, García González Fernando, \\ Navarro Martino Rey David Sigfrido, Spíndola Flores Fabiola
}

Business Department, Iberoamericana University of Puebla, San Andrés Cholula, Puebla, México

\author{
Email address: \\ hector.villanueva@iberopuebla.mx(V.L. H. Manuel) \\ ${ }^{*}$ Corresponding author
}

\section{To cite this article:}

Villanueva Lendechy Héctor Manuel, Tapia Villagómez Ivonne, García González Fernando, Navarro Martino Rey David Sigfrido, Spíndola Flores Fabiola. Social Entrepreneurship and Empowerment of Rural Women: Artemali Case. Science Journal of Business and Management. Vol. 7, No. 4, 2019, pp. 80-86. doi: 10.11648/j.sjbm.20190704.12

Received: July 8, 2019; Accepted: August 19, 2019; Published: September 4, 2019

\begin{abstract}
In the municipality of Tepatlaxco de Hidalgo, a federative entity of Puebla, in the country of Mexico, 30 rural women started the business of manufacturing and marketing handicrafts with the pine leaf, called "ocoxal", with a sustainability perspective, to improve the quality of life of their families motivated by economic deprivation. This research was of qualitative type, applying inductive methods and convenience sampling, documentary techniques and panel interviews in situ, worksheets and an interview guide. Six women from the municipality of Tepatlaxco were interviewed, who are part of the management of the Artemali company. The data obtained were analyzed based on two variables: social entrepreneurship and empowerment of rural women. In this first part of the research, three categories were used: own business, learning and sustainability. The results of the interviewees showed that the business is profitable, which has allowed some aspects of the quality of life of their families to improve. It is also sustainable because they limit the amount of ocoxal to be collected from the forest, carry out cleaning campaigns of the forest, participate in breast cancer prevention campaigns and give courses to children to take care of the forest. In addition, they have entered commercially in Europe, in fairs that promote the sale of handicrafts several countries.
\end{abstract}

Keywords: Social Entrepreneurship, Empowerment, Learning, Innovation, Sustentabilidad

\section{Introduction}

Neoliberal capitalism is an economic system that has favored the accumulation of capital, exacerbated competitiveness, hyperconsumism, hyperindividualism, the depredation of natural resources has prioritized efficiency and productivity over decent work, of a fair distribution of Wealth and moderate use of natural resources. The consequences have been galloping poverty and polarization in the distribution of income and profits, to the point that less than $10 \%$ of the population accounts for $90 \%$ of the world's wealth.

Therefore, governments must create more solidarity-based economies that promote the moderate use of natural resources, the use of clean energy, the reduction of poverty, the access of the entire population to quality formal education, a system of more equitable health, as well as contributing to the incorporation of women and people with disabilities into the formal economy, in equitable conditions. An international initiative to which countries can be incorporated are the 17 objectives for Sustainable Development, proposed by the United Nations Organization (UN).

Mexico is no exception to the negative impacts of neoliberal capitalism, Mexican governments have favored the establishment of a hierarchical capitalist system, run by few business families, which are allied to the political class and religious leaders. The most supported economic unit is the capitalist company, whose purpose is to operate at low costs, generate many profits and use fiscal strategies to pay few taxes or not pay them, due to the alliances they have made with the political class, which generates a spiral rising corruption and impunity that harms the citizens of the lowest 
economic strata.

Therefore, the government, universities, civil society, among other actors, must promote and promote the creation of companies that generate more positive social and environmental impacts, ventures that solve social needs, ventures that use natural resources wisely., enterprises that contribute to improve the quality of work life, that is, social enterprises. The neoliberal capitalist system has also encouraged the patriarchal hegemonic structure, however, for different reasons, more and more women are incorporated into paid, formal and informal economic activities, some of these women are employed in government, in companies or create Your own companies.

In Mexico, since the 1960s, there have been changes in the gender roles of households, in part, as a result of the defense of women's rights, which have been legitimized. Consequently, urban women are increasingly interested in their advancement and career advancement. In rural areas, women are forced to work in a paid way or to start business because of the poverty in which they live. Women entrepreneurs start their business with the scarce material resources they have, with little or no academic and administrative preparation, with or without the support of their partner. However, women also play their other roles in parallel, that is, they educate their children, perform domestic activities and seek care for their partner, therefore, the woman performs a double and triple working day. This indicates that the entrepreneurship of women must overcome many obstacles so that it can be maintained and be profitable.

In the investigation of the artisans of the Artemali company, they will also be mentioned as entrepreneurs, women entrepreneurs and indigenous rural women, any expression is a synonym.

\section{Social Entrepreneurship}

Social enterprises as productive structures have an imprint of social benefit, and in this sense it can be affirmed that they are alternative forms of enterprises within a neoliberal capitalism that shelters organizations oriented to profit, to the accumulation of capital, and to enriching few people causing the polarization between the city and the countryside. In contrast, in social enterprises, cooperative work and decision making are promoted in a consensual or democratic manner: the partners are simultaneously the workers as they determine how and in which way the benefits will be applied and the profits will be distributed. In addition, they use management techniques that contribute to the sustainability and sustainability of the enterprise. The characteristics of social entrepreneurship, after having reviewed some authors [1-4] are the following:

1. The embryonic germ of the social good;

2. A sustainable social change, which implies: a) The sustainability of the organization (financial independence and profitability) and b) The achievement of social change in a continuous manner;

3. The improvement of the conditions of at least one group;

4. The use of management methods and techniques;

5. The possibility of new enterprises eliminating codependency;

6. It is considered that social entrepreneurship is developed as part of a dynamic in which it generates and socializes knowledge, agents of change, while strengthening the social capital of its members;

7. Search solutions for social problems through the construction, evaluation and pursuit of opportunities that allow the generation of social value sustainable.

Social entrepreneurship, unlike traditional entrepreneurship, does not start with the criteria for generating income and profits, start of the social problem approach to solve. This problem must be stated from its causes and then, investigate all the actions that have been taken to solve it, in order not to propose what has already been done. Subsequently, a question is enunciated that triggers the creative process to find a socially and economically feasible solution. In this regard, there are several social business models that can be used (for example, the B business systems), the important thing is that the business generates a sustainable social impact.

\section{Women's Rural Empowerment in Mexico}

The use of the word female empowerment has its roots in European feminist movements and in the United States of America. In Latin America, the feminist movement emerged at the end of the 19th century and is currently struggling to deconstruct a Eurocentric, colonial, patriarchal and Catholic heritage, which generated genocide, slavery and a lacerating sexual violence of Latin American natives, mainly towards women, and in turn, build a feminist movement that in addition to modernity amalgamate the knowledge of native cultures [5].

The use of the term female empowerment in Latin America, is not initially related to the generation of companies, not even traditional companies, is associated with movements of social change, for example, the right to an academic education like men, the right to vote and reproductive rights, among others. Subsequently it was related to access to executive positions and a salary similar to the man in positions, when similar jobs are held. A strategy of feminine empowerment is the association and collective action of women to understand and uproot the idea that male domination is inevitable and irreversible and thus break the chains of women's subordination to men. This process accompanies training in gender and reproductive education issues, it is not linear and the important thing is the continuity and commitment of grouped women. The process of female empowerment has three dimensions; personal, collective and close relationships. Some of the collective actions influence the transformation of structures and institutions that support gender discrimination. 
Rural women's desire for a construct that allows them equity between their role in the family, their economic and political roll and access to land and decision-making have generated the phenomenon of feminization of the countryside or agriculture [6-8]. For that reason, more women start their own business with the agricultural resources available to them or granted to them through remittances, thus initiating a process of personal, economic and political-social empowerment [9-11]. The empowerment of rural women is related to variables such as academic degree, investment in business, engaging in commerce, high degree of willingness for community work, satisfaction in doing paid work, among others [9].

\section{Methodology}

A protocol was conducted in order to clarify the research done and synthesized as follows:

The problem analyzed: How rural women can improve their family's quality of life through social entrepreneurship and empowerment. The context: the investigation was carried out on February 1, 2019 in the company Artemali, in the municipality of Tepatlaxco de Hidalgo, federal entity Puebla, country México (primary source of information). Type of investigation: qualitative paradigm of interpretative nature; therefore, the inductive method was invoked. The techniques used were documentary and in situ panel interview. The objective was: To find out in situ how the rural women work social entrepreneurship and how they develop empowerment. The variables analyzed were: a) Entrepreneurship b) Female rural empowerment. In this first part of the investigation, the categories analyzed were: Self-owned business, learning and sustainability. The analysis was developed by: the instrument being the semi-structured questionnaire that was applied to all members of the company.

The software used was ATLAS-ti, a software which quantities the occurrences between the categories and depict trees of semantic relationship, was used to process the data. The procedure was as follows: before conducting the field research, the eight categories were determined based on the literature review and the experience of the researchers. Then followed an analytical reading of the transcription of the interview that had been carried out. It was encoded, identifying the 33 subcategories. The data was then entered into the software for analysis, from which the co-occurrence table and semantic networks were created and encoded. For the purposes of this stage of presenting the results and being the most relevant, only the networks of the self-owned business categories and decision making of the own business were conducted. The research aimed to analyze the relationship between entrepreneurship and the empowerment of indigenous rural women. The results and conclusion are shown in the following sessions.

\section{Results}

After analyzing the data related to the variables of community tourism and indigenous women's rural empowerment and their categories, a semantic network was generated involving the self-owned business (own business), which is related to other categories and subcategories:

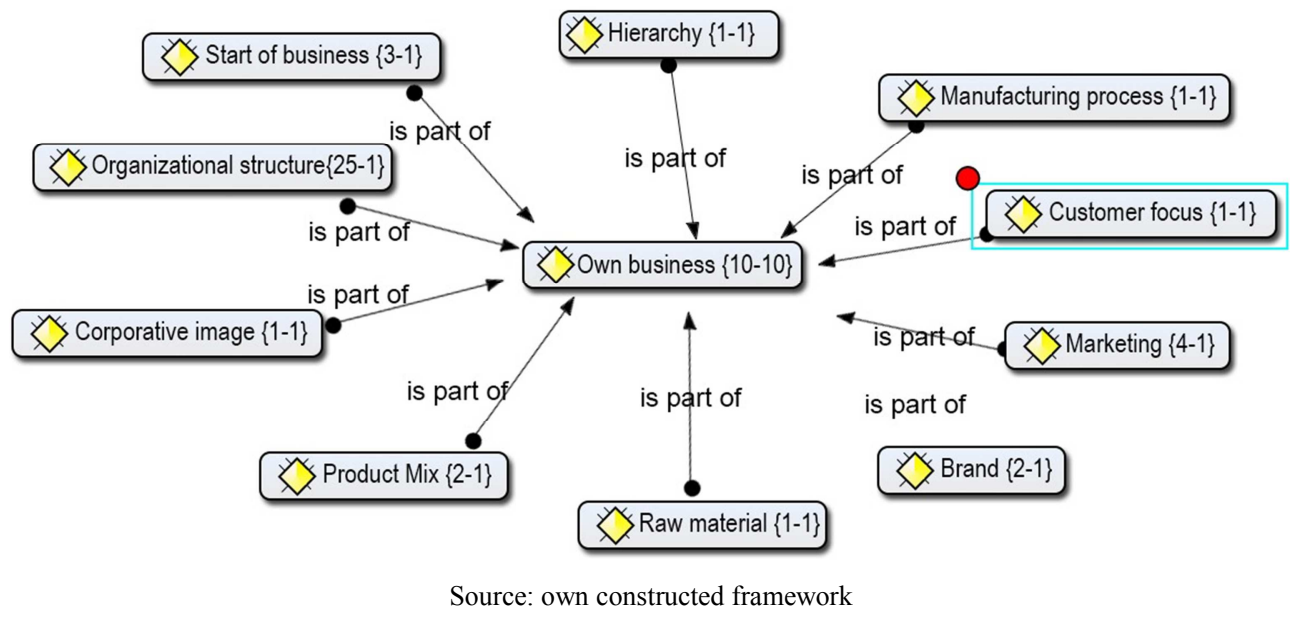

Figure 1. Semantic network of the category of self-owned business (own business).

In this investigation, two categories of the rural women's empowerment variable were analyzed, the first was selfowned business and the second was organizational learning. The mentioned categories are divided into several subcategories that were also analyzed. The software that was used was ATLAS-ti, to generate semantic relationships from co-occurrences, as shown in Figure 1. Concurrency is related to quantities that result from counting the number of times two or more lexical units are present at the same time, in the same contexts, that is, in the interview.
The first category related to rural female empowerment that was analyzed was self-owned business, which was divided into the subcategory called organizational structure. In the company Artemali, the structure consists of four hierarchical levels. The first is the manager, the second, the president, the third, the vice president, the fourth, the treasurer, the director of the reception department, the director of the quality department, the director of the sales department and the director of the department of labeled. All workers are women and none have a university degree. 
The company is legally established, its name is a company of limited social and economic social responsibility. At the beginning, the company belonged to an agrarian movement and in 2008 they were invited by the ejido commissioner of the Indigenous Peoples Convention Center, where they observed the work of artisans from the municipality of Venustiano Flores Ojeda, which is a town near the city of Zitácuaro in the state of Michoacán, Mexico. The women of the city of Zitácuaro wove crafts with ocoxal and this inspired the women of the Artemali company to make use of the forest resources, creating their own crafts that generate an important source of income for their families.

On the other hand, business decision-making is carried out in a consensual manner and the permanence they have in each of the positions lasts approximately two to three years. It is the task of the internal committee to rotate people in these positions. The category of self-owned business is also divided into the marketing subcategory. The businesswomen of Artemali, make decisions of their points of sale, sometimes, they plan their points of sale and other occasions, invite them to sell in a fair or in a university. When they attend a fair or other point of sale, each woman wears her own handicraft and sells it, the income related to her sale is for her, therefore, the income of each woman depends on her abilities as a seller and preference of customers who purchase their merchandise. However, women are supportive because they sell the goods of their partners when they cannot attend and give them the income from the sales. The self-owned business category is also divided into the subcategory of the trademark.

The Artemali company began its commercial operations using the brand of Artemali Ocoxal. The word Artemali is divided into two parts, the first is "art" because they make "crafts" and "mali" that derives from "malinche" which means woman in the Nahuatl language, which is the native language most commonly spoken in Mexico and that have most influenced Mexican Spanish. The word "ocoxal" refers to the ocote leaf and its meaning is divided into two words: "oco" which is pine tree leaf and "axal", which means sand, therefore, "ocoxal" means "sand that falls from the pine". However, the women entrepreneurs of Artemali did not register their trademark at the IMPI (Mexican Institute of Industrial Property) because they did not know that they had to register it but another artisan, owner of another company that also makes handicrafts with the pine leaf or "ocoxal" in the state of Jalisco in Mexico, if it registered the word "ocoxal". The aforementioned, caused that the women entrepreneurs of Artemali cannot use the brand "Artemali Ocoxal" and can only use the brand "Artemali", which is also the name of the company.

In relation to the above, to perform another type of analysis, we present the arguments of the transcripts related to the category of self-owned business. The name of the interviewer is Ivonne. The name of the interviewee is Pilar.

Ivonne: Now you are happy, but how did all of this begin? How did you get organized? How many women were there in the beginning?

Pilar: the ejidal commissioner invited us to a meeting that took place at the indigenous peoples' convention center where we had the opportunity to see the artisans from a municipality of Venustiano Ojeda, a municipality of Zitácuaro, Michoacán who were weaving baskets, the event took 3 days and they weaved these 3 days, so they were our inspiration and we said, we also have our mountain and we can do the same productive activity.

Ivonne. How do you come to an agreement? I imagine that you meet and decide that you are going to produce, you take the production task home and then you bring the product and you classify it. Is that so?

Pilar. Yes, our organization chart of how we are organized internally consists of a manager, an operative president who practically does all the work and a vice-president. We have a treasury, a treasurer, we have departments, we have a reception department, a quality department, a labeling department and a department. In the sales department, all of us participate in something. Oh and the surveillance, there is no one who does not have a responsibility, so we tell ourselves, we are a gear. If you work, the other works. And everything is going to work, and then we share the work, and we decide about the characteristics of the orders. After that it arrives at the reception department and then it goes to the department of quality. And if the quality is not good enough we send it back.

Along the same lines, the semantic network of the learning category and its subcategories were also created, which is the following:

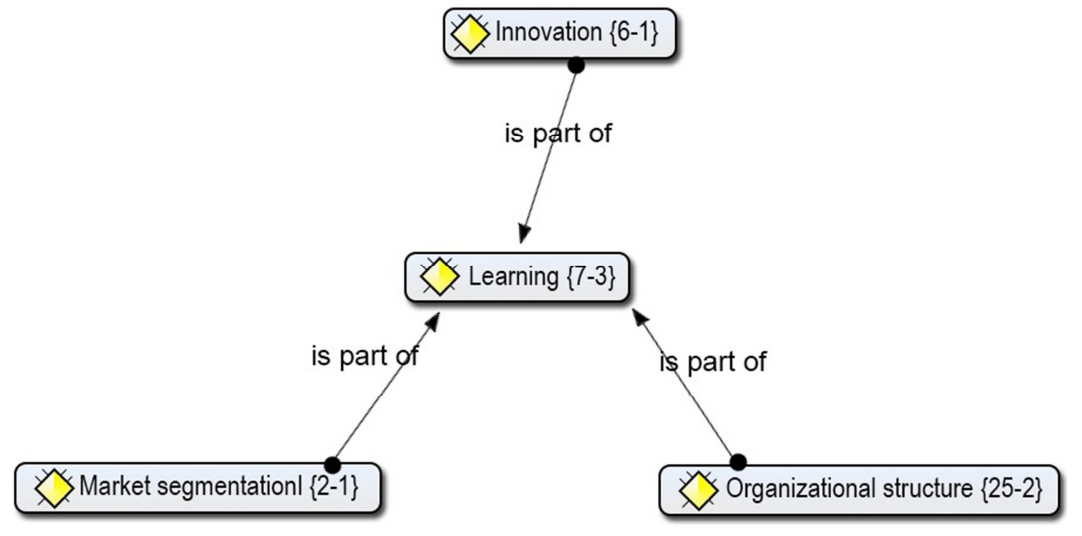

Source: own constructed framework

Figure 2. Semantic network of the category of learning. 
The learning category was also analyzed based on the relationship with the subcategories: innovation, market segmentation and organizational structure, also using the ATLAS-ti software. This software was used to determine the co-occurrence between variable and categories. The concurrence is related to the amounts that result from counting the number of times that two or more lexical units are present at the same time, in the same contexts, that is, in the interview.

The strongest relationships were in the learning category and the subcategories of organizational structure and innovation. The women entrepreneurs of the Artemali company, decided to create a quality department and a line of innovative products to make new products continuously. They made an alliance with a shoemaker in their municipality to manufacture footwear with the crafts they make and with a fashion designer from the federative entity of Guanajuato in the country of Mexico, to make "ocoxal" buttons that the designer will sew on Sacks he makes.

The businesswomen of Artemali, investigate the tastes and needs of their customers and follow the latest fashion trends, the above, allows them to segment their market to meet it with innovative products. They said that their products make them thinking about their customers and not their own tastes. They attended the fair "The Five Continents" held in the city of Italy in the country of Italy and sold many of their crafts because consumers liked them. In addition, they observed that attendees like neutral colors and small crafts because the dimensions of their homes are small, the above will allow them to get to know their customers better for the next time they travel to the European continent.

Regarding to this, in order to conduct another type of analysis, the fragments of the transcriptions related to the learning category are presented. The names of the interviewers are Ivonne and Fabiola. The name of the interviewee is Pilar.

Fabiola: you were talking about a line of innovation when Dr. Ivonne asked about the 5 production lines. What do you mean by this innovation?

Pilar: we mean that we can't only produce baskets, we can't just provide one line, even now the innovation is that it's not just sewn, but also woven, so we always want to be number one, to be at the forefront and, above all, to satisfy our consumers. We have well defined our market, the people who buy from us and we always want to give our best and we are innovating and therefore we put it as a guideline because every year we are finding something new, we empower each other because here no one is more no one is less. We empower everyone.

Ivonne: it is important what you mention in terms of taking decisions in a consensual way, that is to say, everybody has to agree to decide what is going to be produced. Where are you going to market yourself? And do you agree on other business decisions?

Pilar: yes, the decisions regarding innovation are collective, because we all have ideas and we all can design and be designers. Those are collective decisions regarding marketing. We want to sell. The servant is the one going door to door and checks which fair we are going to attend. Besides the learning that allowed innovating their products, there was also learning involved in other areas, for example, to make the trip to Italy, the women learned the basics of Italian in a short time so they could sell their products, as shown in the following transcription:

Fabiola: What did you learn?

Pilar: Many contrasts, being the first time, without knowing Italian, I tell the colleague that we were so excited that we did not feel the 15-hour trip to Milan, when we arrived and set up our stand, with the canvas that said Mexico being happy that we finally achieved a goal we had in the company. We didn't know Italian, but we had so much support from the Mexican community in Milan that in 12 hours we learned the basics and if we couldn't express something using signs, an Italian designer would help us. I admire the Italians even though I don't speak their language but still we could understand each other. It was really important to get to know this big market that welcomed us, bought from us and got to know us for the first time. We experienced that if we could venture into this market, getting to learn it, we could know what it wanted and the most amazing thing were the Swedish people, being our best buyers. They were very pleased with our products.

The research also analyzed the ATLAS-ti software, the sustainability category, which was more strongly related to the subcategory of raw material use. The businesswomen of Artemali decided to collect between 1 and 3 kilos of ocoxal per person each time they climb the forest, therefore, annually they collect approximately 3 cubic meters. These actions are sustainable because they do not reduce the amount of "ocoxal" that serves as fertilizer to the forest land, contributing in turn to the preservation of the flora and fauna of the place, otherwise the ecosystem would be unbalanced.

The above, said Juana, artisan of the Artemali company when asked about the decision to collect a small amount of "ocoxal":

What they want to do is make aware of what the forest is being, create awareness, apart from what is our raw material, we see it that way, it is compost for the other forest...

The sustainable actions of artisans are contrasted with the activity of brick and coal manufacturers in that region, who, every time they go up to the forest to collect "ocoxal" do so in an excessive way, collecting approximately 3.5 tons of ocoxal to use them in the manufacture of its products, contributing to the shortage of fertilizer for the land and breaking the balance of nature.

The interviewee named Juana also talked about the way in which brick and coal manufacturers collect "ocoxal":

...they arrive and unfortunately they have no conscience and carry everything they find, large quantities, fill 3 ton trucks...

The sustainability category was also related to the education subcategory, because the artisans of the ocoxal 
have taught herbalism courses to the general public based on traditional knowledge. They also participated in the construction of the Center for Environmental Culture with other members of the municipality of Tepatlaxco de Hidalgo. In that place, traditional herbalism courses will be taught. It should be mentioned that the construction of the center was done using traditional knowledge to build houses, therefore, the roof was made with ocoxal and zacatón and the walls are made of adobe. Other actions of sustainability of the artisans of Artemali have been the cleaning and preservation of the flora and fauna of the Iztacciuatl-Popocatepetl National Park, which have been recognized every year by the government agency called Federal Attorney for Environmental Protection (PROFEPA) because it has given them the recognition of forest preservatives, distinction to the people or organizations that protect the mentioned national park.

\section{Conclusion}

The objective of the research was achieved because the relationship between the entrepreneurship of Artemali's rural women and their empowerment was identified, which presented certain gradients. In this regard, it is worth mentioning that it is common to speak of empowerment in a binary way, meaning that empowerment manifests itself or not, without there being any middle terms. However, in Artemali we observe that there can be a process of empowerment of women without them lacking a male partner. The interviewees affirmed that their partners came home from work and helped them in the elaboration of the handicrafts together with their children. A degree of cooperation among them was observed which was partly driven because the women brought economic resources to the home favoring the improvement of some living conditions in these families. Furthermore, it is worth mentioning that men are not forbidden to enter the organization. In fact, at the beginning of Artemali, two of its thirty members were men but they decided to leave the company stating that it was only for women.

The artisans of Artemali are accustomed to making decisions collectively because it has generated positive results for them. For example, admitting members, determining marketing channels and points of sale as well as innovating other products. As a result of this, the company participated in the "Five Continents Fair" in Milan, Italy. Another example is the incursion in the footwear market with ocoxal decorations and the alliance with a fashion designer from Guanajuato for the manufacture of buttons for bags. Also, the creation of the five product lines they currently have (home, office, accessories, innovation and training courses) and the way in which the income derived from sales will be distributed, which depends on the effort of each of the members, is notable.

The women have carried out outstanding sustainable actions, such as the collection of garbage from the Iztacciuatl-Popocatepetl National Park and the moderate collection of their raw material, the ocoxal, receiving the recognition of PROFEPA as guardians of the forest. They have also taught solid waste separation courses to children in the Tepatlaxco de Hidalgo community. In addition, they participated together with other members of the community of the construction of the Center of Environmental Culture, in which courses of traditional herbalism will be taught, in an exercise of knowledge recovery.

The artisans took actions that have benefited their community such as the dissemination and promotion of a breast cancer screening program, in which their convincing work was crucial in order to achieve that some women with health problems had access to free medical services and would be able to overcome the machismo that prevails in the community, which prevented them from going for a diagnosis.

On a different subject, the efforts of women entrepreneurs to create an image through the design of a brand were observed. However, due to the lack of information and a more technical business culture, they did not register their brand that showed their identity with the ocoxal being the raw material of all their products and thereby lost the right to use this word. This seems to be a contradiction since it is a Nahuatl word of common and current use identifying them with the environment in which they are immersed. This invites us to reflect on the need to train this type of businesswomen to protect their brands and some of the innovations they pursue.

\section{References}

[1] Palacios, G. "Emprendimiento social: integrando a los excluidos en el ámbito rural" Revista Scielo (en línea), Vol. 4, No. 16, 2010. Consultado el 24 de marzo de 2018. Dirección de internet: http://www.scielo.org.ve/scielo.php?script=sci_arttext\&pid=S 1315-95182010000400002.

[2] Kliksberg, B. (2011). Emprendedores sociales. Los que hacen la diferencia. Temas Grupo Editorial.

[3] Alonso, D., González, N. and Nieto, M. "Emprendimiento social vs innovación social" Cuadernos Aragoneses de Economía, Vol. 24, No. 1-2, 2015, 119-140.

[4] Guzmán, A. y Trujillo, M. "Emprendimiento Social”, Vol. 24, No. 109, 2008, 105-125, consultada el 7 de junio de 2018. Dirección de internet: http://www.redalyc.org/pdf/212/21211518005.pdf.

[5] Bard, G. "Pensamiento feminista latinoamericano" Revista Scielo (en línea), Vol. 11, No. 22, 2017, consultada el 1 de agosto de 2019. Dirección de internet: file://C:/Users/hvill/Documents/feminismo\%20América\%20 Latina-Bard.pdf.

[6] CEDRSSA, 2014. La mujer y su aportación en el desarrollo rural file://C:/Users/hvill/Documents/La\%20mujer\%20ruralaportación $\% 20 \mathrm{en} \% 20 \mathrm{el} \% 20 \mathrm{DRS}-\mathrm{CEDRESSA}$.pdf.

[7] López, V. y Rojas, O. "Rezagos en el nivel de autonomía de las mujeres rurales mexicanas en la primera década del siglo XXI" Revista de Estudios demográficos y urbanos (en línea), Vol. 32, No. 2, 315-354, 2017, consultada en internet el 7 de abril de 2018. Dirección de internet: https://dx.doi.org/10.24201/edu.v32i2.1644. 
[8] Córdova, R. Acceso de las mujeres a la tierra y patrones de herencia en tres comunidades ejidales del centro de Veracruz. Relaciones. Estudios de Historia y Sociedad, Vol. XXIV, 2003, 93.

[9] Vázquez, D., Mortera, D., Rodríguez, N., Martínez, M., Velázquez, M. G. (2013) "Organización comunitaria de mujeres: del empoderamiento al éxito del desarrollo rural sustentable". Revista de Estudios de Género, la ventana (en línea) VoI. 5, 2013, consultada el 30 de marzo de 2018. Dirección de internet: http://www.redalyc.org/articulo.oa?id=88428978011.
[10] Soler, P., Planas, A., Ciraso-Calí, A., Ribot-Horas, A. "Empoderamiento en la comunidad. El diseño de un sistema abierto de indicadores a partir de procesos de evaluación participativa" Revista de Pedagogía Social Interuniversitaria, No. 24, 49-77, 2014.

[11] Deere, C. y León, M. (2000). Género, propiedad y empoderamiento: tierra, Estado y mercado en América Latina, Bogotá, Colombia: Tercer mundo Editores en coedición con el Programa de Estudios de Género, Mujer y Desarrollo, Facultad de Ciencias Humanas, Universidad Nacional de Colombia.

\section{Biography}

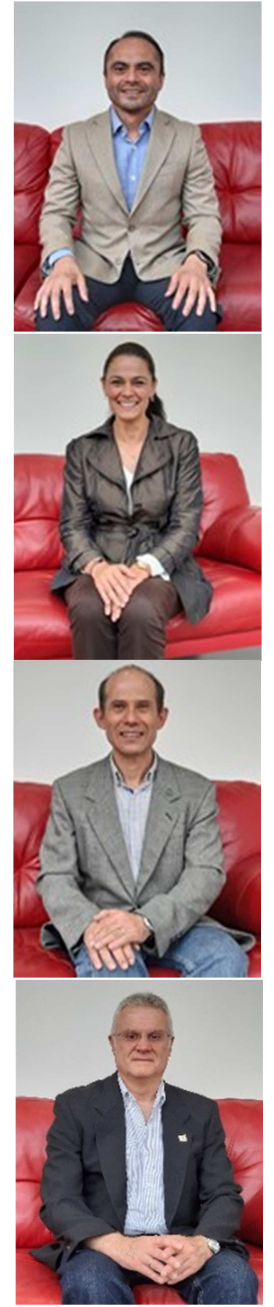

Villanueva Lendechy Héctor Manuel. Doctor in Administrative Sciences and Management for Development. Diploma in process reengineering. He has been an entrepreneur and business consultant. He has participated as a speaker at international conferences and published in specialized magazines. Author of the book "Game and socialization of knowledge: case of the International Jazz Festival of the Veracruzana University". Coordinator of the book "Emerging paradigms of administration: innovation, sustainability and social entrepreneurship". Full professor and coordinator of the Doctorate in Administration of the Business Department of the Iberoamericana University of Puebla. Research lines: 1) Social entrepreneurship and the empowerment of rural women; 2) Social innovation.

Tapia Villagómez Ivonne. Degree in Administration, Master in Management and Doctorate in Education and Organizational Development. Consultant on organizational development, human talent and social responsibility issues. He has participated as a speaker in national and international conferences. He has published in specialized magazines, dissemination, written press and digital media. Co-author of the book "Education in Mexico, from imaginary to reality" and coordinator of the book "Emerging paradigms of administration: innovation, sustainability and social entrepreneurship". She is currently director of the Business Department of the Iberoamericana University of Puebla. Research lines: 1) Social entrepreneurship and the empowerment of rural women; 2) Social innovation.

García González Fernando. Degree in Public Accounting from the Autonomous University Benemérita de Puebla. Master in Quality Engineering from the Iberoamericana University of Puebla. Diplomas in Integral Development and University Teaching in competitions. He has professional experience in the financial sector. Full-time professor and coordinator of the Master in Administration of the Iberoamericana University of Puebla. He received the "Eusebio Francisco Kino S.J" medal twice for his teaching performance. Professor certified by the National Association of Colleges and Universities of Accounting and Administration. He has published articles in international conferences. Research line: social entrepreneurship and the empowerment of women.

Navarro Martino Rey David Sigfrido. Doctor in business administration and management, Master in administrative systems, Master in quality engineering. Diplomas in: Quality and Productivity. Quality Service Specialization in Japan and Jonha in Restriction Theory, Industrial and Systems Engineer. Professional experience: Quality analyst (glass industry), operations and process research analyst. Consultant and business advisor. Postgraduate business coordinator. Consultant and business advisor of several Mexican companies. Full time professor of the Iberoamericana University of Puebla. Professor in bachelor, master and doctorate in different universities. He has published articles in International Research Congresses. The lines of research are focused on social entrepreneurship and empowerment of women.

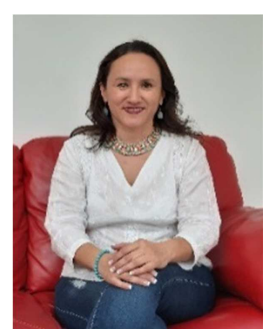

Spíndola Flores Fabiola. Graduated from the Bachelor of Business Administration and Master in Management transformation by the Iberoamericana University of Puebla, she has more than 20 years of professional experience in Higher Education Institutions, working in positions such as: job opportunities, professional practices, international students, graduates office, external relationship (business-university), human resources and organizational development department. Actually works as a staff in the Business Department, teaching in two levels, bachelor and master. He has published articles in International Research Congresses. The lines of research are focused on social entrepreneurship and empowerment of women. 